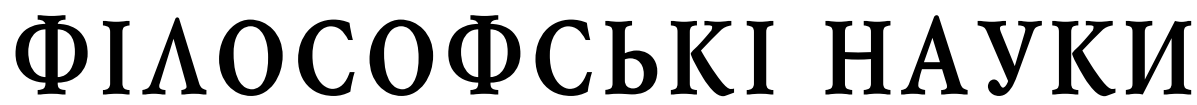

\author{
DOI: https://doi.org/10.32839/2304-5809/2021-6-94-28 \\ УДК 316.285:101(316.65)
}

Авер'янова Н.М.', Воропаева Т.С. ${ }^{2}$

Київський національний університет імені Тараса Шевченка

\section{СТАНОВЛЕННЯ І РОЗВИТОК КОНФЛІКТОЛОГІЧНИХ ІДЕЙ В ІСТОРІї ФІЛОСОФСЬКОї ДУМКИ}

\begin{abstract}
Анотація. У VII-VI ст. до н.е. у Давньому Китаї та Стародавній Греції виникають перші фрілософрські вчення про протилежності та їхню роль у суспільстві. Античні мислителі вивчали різні аспекти суперечливої взаємодії між людьми, соціальними групами, суспільствами і країнами, а також проблеми згоди і протиборства, війни і миру. Розроблене римськими юристами право стало потужним механізмом для врегулювання різного роду протистоянь. Якщо в античній фрілософрії джерело різних протистоянь мислителі вбачали у природі та бутті, то в середньовічній фрілософії це було пов'язано 3 відсутністю або нестачею добра, Бога в душі людини. В епоху Відродження мислителі звертаються до класичної спадщини Давньої Греції та Риму, вони засуджують будь-які протиборства й соціальні зіткнення. В цю епоху були сформовані дві протилежні думки, які пояснювали причини протиборств у сощіумі, адже одні автори бачили причину конфліктності у недосконалій системі соціальної взаемодії, а інші - у недосконалості людської особистості та ії̈ негативних рисах. Отже, наукове осмислення конфліктів починається в ранній період становлення фрілософської думки, а розробка фрундаментальних конфліктологічних концепцій у 1950-1970 роках. Концептуальним методологічним ядром нашого дослідження $є$ інтегративний аналіз конфліктів як складно організованих явищ. У даній статті інтегративний підхід базуеться на взаємодії історії фрілософрії, історії ідей та українознавства. Саме інтегративний підхід дозволяє випрацювати широку методологічну інтерпретацію конфлікту, яка допоможе: а) знайти відповідь на питання, яким чином можна найоптимальніше врегулювати конфрлікти, котрі загрожують цілісності й стабільності суспільства і держави, б) зрозуміти конфлікти як необхідну умову для повноцінного розвитку соціуму (i будь-яких соціальних груп), намагаючись актуалізувати той потенціал оновлення, який характерний для конфліктної взаємодії. Інтегративний підхід дозволяе проаналізувати й систематизувати причини й чинники конфліктизації певного соціуму, які дають найбільш повну картину появи та ескалації будьякого конфлікту. Інтегративний підхід дозволить подолати обмеженість існуючих методологічних концепцій і поєднати найбільш дієві засоби деконфліктизації та стабілізації соціуму.
\end{abstract}

Ключові слова: конфрлікт, конфрліктологічні ідеї, фрілософрська думка, історія ідей, українознавство, Україна, Росія.

Averianova Nina, Voropayeva Tetiana Taras Shevchenko National University of Kyiv

\section{FORMATION AND DEVELOPMENT OF CONFLICTOLOGICAL IDEAS IN THE HISTORY OF PHILOSOPHICAL THOUGHT}

Summary. In the VII-VI centuries. b.c. in ancient China and ancient Greece, the first philosophical teachings about opposites and their role in society. Ancient thinkers studied various aspects of the contradictory interaction between people, social groups, societies and countries, as well as the problems of consent and confrontation, war and peace. The law developed by Roman jurists became a powerful mechanism for settling various conflicts. If in ancient philosophy thinkers saw the source of various oppositions in nature and being, in medieval philosophy it was due to the absence or lack of good, God in the human soul. In the Renaissance, thinkers turned to the classical heritage of ancient Greece and Rome, they condemned any confrontation and social conflict. In this era, two opposing views were formed, which explained the causes of conflict in society, because some authors saw the cause of conflict in the imperfect system of social interaction, and others - in the imperfection of the human personality and its negative traits. Thus, the scientific understanding of conflicts begins in the early period of formation of philosophical thought, and the development of fundamental conflictological concepts - in 1950-1970. The conceptual methodological core of our study is an integrative analysis of conflicts as complexly organized phenomena. In this article, the integrative approach is based on the interaction of the history of philosophy, the history of ideas and Ukrainian studies. It is an integrative approach allows to develop a broad methodological interpretation of the conflict, which will help: a) find an answer to the question of how best to resolve conflicts that threaten the integrity and stability of society and the state, b) understand conflicts as a necessary condition for the full development of society (and any social groups), trying to actualize the potential for renewal, which is characteristic of conflict interaction. An integrative approach allows you to analyze and systematize the causes and factors of conflictization in a particular society, which give the most complete picture of the emergence and escalation of any conflict. The integrative approach will overcome the limitations of existing methodological concepts and combine the most effective means of deconfliction and stabilization of society.

Keywords: conflict, conflictological ideas, philosophical thought, history of ideas, Ukrainian studies, Ukraine, Russia.

\footnotetext{
ORCID: https://orcid.org/0000-0002-1088-2372

2 ORCID: https://orcid.org/0000-0001-8388-7169
} 
$\Pi$ остановка проблеми. Проблема становлення і розвитку конфліктологічних ідей в історії фрілософрької думки є доволі актуальною і займає важливе місце в системі сучасної соціогуманітаристики. У коло даної проблематики входять і питання російсько-українського збройного конфрлікту неоколоніального типу, що триває на території України вже восьмий рік, конструктивне вирішення якого має величезне практичне значення для всієї планети. Подальший цивілізаційний поступ України вимагає не тільки захисту національної незалежності, державного суверенітету і територіальної цілісності держави, але й досягнення стабільності на глобальному й регіональному рівнях та загальнонаціональної єдності. Надзвичайно важливою у цьому плані $є$ припинення російсько-українського збройного конфлікту, деконфліктизація українського суспільства та реінтеграція населення окупованих територій. Ця проблема має сьогодні практичну актуальність для України. Вирішення ціеї проблеми неможливе без розробки теоретико-методологічних засад на основі інтегративного підходу [36].

Аналіз останніх досліджень і публікацій. Відомо, що історія фрілософрї̈ - це розділ філосоdoii, що вивчае історичні типи фрілософоï, фрілософрські системи окремих мислителів, розвиток фрілософрських шкіл тощо. Те, що історія фрілософської думки обов'язково містить критичний аналіз попередніх фрілософських концепцій, який «вплітається» у контекст репрезентації власних ідей і поглядів самих істориків фрілософрї, демонструе творча діяльність багатьох давніх мислителів і сучасних учених, зокрема, таких, як Аристотель, В. Бурлей, В. Віндельбанд, М. Гартман, Г. Гегель, М. Г. Гейнце, Ф. Ібервег, Е. Рейнгольд, Т. Стенлі, К. Ясперс; В. Асмус, І. Бичко, М. Булатов, П. Гайденко, Л. Гармаш, В. Горський, А. Горфункель, С. Крилова, В. Лісовий, В. Лях, А. Муравйов, В. Нічик, В. Петрушенко, Д. Прокопов, В. Титаренко, Н. Хамітов, В. Шинкарук, В. Яковлєв, В. Ярошовець та інших.

Аналіз історії фрілософрської думки уможливлюе теоретичну реконструкцію, інтерпретацію та критичне осмислення основних конфліктологічних ідей, які представлені у різних фрілософських концепціях. Такий аналіз здійснили А. Анцупов, В. Асмус, А. Івін, Г. Майоров, В. Светлов, В. Семенов, Ю. Смагін, А. Шипилов та інні вчені $[2 ; 3 ; 11 ; 14 ; 22 ; 23 ; 24]$. Але ці вчені не застосовували у своїх дослідженнях інтегративний підхід, що дозволяє виявляти внутрішні зв'язки в системі конфліктологічних знань, спадкоемність та взаємозумовленість тих чи інших ідей, які виникали у представників різних фрілософрських шкіл та напрямів. Саме така теоретична база необхідна для цілісного розгляду становлення і розвитку конфрліктологічних ідей в історії фрілософрської думки.

Виділення невирішених раніше частин загальної проблеми. Наші попередні теоретико-емпіричні дослідження були присвячені проблемам конфрліктизації та деконфрліктизації соціуму, особливостям російсько-українського збройного кондрлікту на теренах України, трансформації колективної ідентичності громадян України у 2014-2021 роках. Було зроблено висновок про необхідність інтегративного осмислення конфрліктизаційних і деконфліктизаційних процесів у соціумі з урахуванням теоретичних, емпіричних і практичних аспектів [35; 36; 37].

Концептуальним методологічним ядром нашого дослідження є інтегративний аналіз конфрліктів як складноорганізованих явищ. У даній статті інтегративний підхід базуеться на взаємодії історії філософії, історії ідей та українознавства.

Відомо, що історія ідей - це наука, яка вивчає історичний процес створення, збереження і трансформації людських ідей. Оскільки історія ідей тісно пов'язана з історією фрілософрiї, історією науки, інтелектуальною історією та історією культури в цілому, то вона може бути й однією із складових інтегративного підходу в рамках багатьох соціогуманітарних досліджень.

Відомо, що поняття «історія ідей» було уведено в науковий обіг американським фрілософром А.О. Лавджоєм (дуже відомою є його книга «Великий ланщюг буття: історія ідеї», видана у 1936 р.), який і став засновником цієї наукової дисципліни. У 1940 р. А.О. Лавджой став засновником і першим редактором «Журналу з історії ідей», а у 1948 р. написав «Нариси з історії ідей». Найвідомішими представниками історії ідей є П. Азар, П.О. Крістеллер, Р. Уеллек, Л. Шпітцер.

Отже, інтегративний підхід, який базуеться на взаємодії історії фрілософрії, історії ідей та українознавства, дозволяе вивчати не просто окремі конфрліктологічні ідеї в історії фрілософрської думки, а взаємодію і взаємовплив таких ідей, вилучаючи нові смисли із вже відомих концепцій, відстежуючи як спадкоємність конфліктологічних ідей, так і процес збереження найкращих досягнень попередніх історичних етапів на наступних етапах розвитку фрілософської думки. Інтегративний підхід дає можливість проаналізувати наступність між різними конфрліктологічними вченнями, а також запустити процес реактуалізації тих конфрліктологічних ідей, які не втратили своєї значущості до цього часу і є важливими для припинення російсько-українського збройного конфлікту на теренах України, деконфрліктизації українського суспільства та реінтеграції населення окупованих територій.

Саме інтегративний підхід дозволяе випрацювати широку методологічну інтерпретацію конфлікту, яка допоможе: а) знайти відповідь на питання, яким чином можна найоптимальніше врегулювати конфлікти, котрі загрожують цілісності й стабільності суспільства і держави, б) зрозуміти конфрлікти як необхідну умову для повноцінного розвитку соціуму (і будь-яких соціальних груп), намагаючись актуалізувати той потенціал оновлення, який характерний для конфрліктної взаємодії. Інтегративний підхід дозволяе проаналізувати й систематизувати причини й чинники конфліктизації певного соціуму, які дають найбільш повну картину появи та ескалації будьякого конфлікту. Інтеративний підхід дозволить подолати обмеженість існуючих методологічних концепцій і поєднати найбільш дієві засоби деконфліктизації та стабілізації сощіуму.

Отже, інтегративне осмислення становлення й розвитку конфліктологічних ідей в історії фpiлософської думки не дістало належного розвитку в попередніх наукових дослідженнях. Це й 
обумовило мету даної статті - проаналізувати найважливіші конфрліктологічні ідеї, які репрезентовані в історії фрілософрської думки (від фрілоcodpiï античності до фрілософрiї епохи Відродження та періоду становлення Новоєвропейської фрілоcodpii) крізь призму інтегративного підходу.

Виклад основного матеріалу. Відомо, що у світі немає жодної країни, суспільство якої б постійно перебувало у безконфліктному стані, адже конфлікт, будучи невід'ємним компонентом людського існування, виявляе себе в суперечливій едності природи й сощіуму, природи й культури, соціуму й людини, людини й людини тощо. Такі суперечності завжди мали місце в історії людської цивілізації, і з плином часу вони набували все більш гострого «звучання», зокрема, в умовах кардинальних трансформацій, які відбувались і відбуваються у межах різних держав, посилюючи конфрліктність у різних сорерах суспільного життя.

Війни, релігійна нетерпимість, відмінність моральних установок, неприйняття цінностей інших груп і спільнот - всі ці явища свідчать про те, що приводи для конорліктів існували завжди. Перші зіткнення й конфрлікти у первісному соціумі відбувались через біологічну й фрізіологічну несхожість людей (всередині власної групи - через психо-фрізичні відмінності, вікові чи статеві особливості, поза власною групою - за принципом «Ми» - «Вони», захищаючи «своїх» і протидіючи «чужим»), а також через початок соціальноекономічного розшарування суспільства.

Конфрлікти (як природний прояв соціального життя і специфічної взаємодії людей і груп) завжди звертали на себе увагу представників різних наук. Предметом досліджень стародавніх мислителів і сучасних вчених упродовж багатьох століть було вивчення суперечностей в соціумі, зіткнення протилежних інтересів, цінностей та мотиващій людей, боротьба між індивідами, окремими групами, країнами, державами, цивілізаціями.

Перші дослідження конфліктних явищ з'явились у VII-VI ст. до н.е. в Давньому Китаї. Тогочасні китайські мислителі вважали, що джерело розвитку всього існуючого міститься у взаєминах властивих матерії позитивних (Янь) і негативних (Інь) сторін, які перебувають у постійному протиборстві й призводять до конорронтації їхніх носіїв. Китайський мислитель ЛаоЦзи наголошував, що фундаментальні першооснови світу Янь (світле) й Інь (темне) не тільки вступають у взаємне протиборство, але й доповнюють одне одного та утворюють Гармонію [34]. Китайський фрілософ Конфуцій закликав людей покращувати звичаї, усувати вади й недоліки, уникати сварок. Він сформулював золоте правило етики: «Не роби людині того, чого не бажаєш собі», яке можна розглядати як одну з перших в історії людства деконфрліктизаційних настанов. Конфуцій стверджував, що злість, зарозумілість, а також конфрлікти, породжують нерівність і несхожість людей. Він наголошував, що схильність до неправди, користолюбство, підлабузництво й упертість не сприяють людському спілкуванню, а доброта, людяність, справедливість, суворе ставлення до себе і шанобливе ставлення до старших людей приносять користь [13, с. 67].
У VII-VI ст. до н.е. у Стародавній Греції виникає фрілософрське вчення про протилежності та їхню роль у суспільстві. Давньогрецький мислитель Анаксимандр стверджував, що речі виникають 3 постійного руху «апейрона» (матеріального начала), з якого виділяються протилежності. «Батько історії Геродот стверджував, що «ніхто настільки не безрозсудний, щоб віддати перевагу війні, а не миру. Адже під час війни батьки ховають дітей, а під час миру - діти батьків» [30]. Давньогрецький фрілософо Геракліт говорив про світ (котрий включає в себе протилежності), як про світ вічний і незмінний, він намагався раціонально осмислити природу конфрронтащійних явищ, представляючи рух речей і явищ як необхідний, закономірний процес, породжуваний боротьбою протилежностей. Мислитель стверджував, що суспільство у процесі свого розвитку постійно перебуває у боротьбі за свое існування, він вважав, що ворожнеча, чвари і сварки є неодмінними умовами суспільного життя, адже «все відбувається через боротьбу і за необхідності» [29, с. 48], а протиборство, в тому числі й війна, е «батько всього і цар всього» [2, с. 29].

Ідеї Геракліта про протиборство як основу всіх речей поділяли й інші фрілософри, зокрема, давньогрецький фрілософр-матеріаліст Епікур, який висловив думку про те, що ворожі зіткнення, завдяки своїм важким наслідкам все ж таки переконають людей жити у мирі та злагоді [30]. Давньогрецький фрілософр-матеріаліст Демокріт розглядав війну як зло, а мир - як велике благо, він виправдовував оборонні війни, спрямовані на захист своєї держави й народу [12, с. 12-16]. За Сократом, зло, скоєне іншому, і $є$ причиною кондлікту, бо викликає відповідну реакцію [11, с. 8-9]. Давньоримський політичний діяч i dpiлософр Цицерон розумів неминучість насильницьких дій між людьми, доводив наявність «справедливого" й «несправедливого» насильства у соціумі. У своєму творі «Про державу» мислитель писав про «справедливу й благочестиву війну», яку потрібно вести для помсти за заподіяне зло, а також для вигнання з країни ворога [31].

У Стародавній Греції був поширений принцип агона (змагальності). Слово «агон» (боротьба, суперництво, змагання), як вираз спірного і суперечливого начала, мало фундаментальне значення і в античній dрілософіï, і в напружених полісних відносинах, і в повсякденному, буденному житті людей (Олімпійські ігри, різні свята, війни тощо) [30]. Агон знаходив своє вираження не тільки в міфологічній свідомості, але й в ідеї військового протистояння, яка розвивалась в історичних роздумах Геродота, Фукідіда й Ксенофонта, у фpiлософрській проблематищі досократиків (що розглядали Космос як єдине утворення), у космополітичних ідеях Гесіода та інших давніх мислителів [23]. У цьому контексті доволі показовими були: 1) проблема протиставлення буття і не-буття у фрілосодрії Парменіда; 2) «дружба» i «ворожнеча» як протилежні елементи у космології Емпедокла; 3) «агональне» начало у dрілософіiі Сократа, де протиставляеться істинне знання неістинним думкам; 4) агон і “суб'єктивна діалектика" у софостів; 5) агон матерії і фороми у фрілософії Аристотеля. Отже, природа «агонального» у фрілософрї елліністичного і римського періодів виражалась, 
перш за все, в еклектичному характері фрілософської думки, де фрілософрiя «проти» розглядалась як справжня фрілософрія [23].

Проблема боротьби Добра і Зла широко репрезентована у давньогрецькій міфології, де $є$ багато сюжетів про тривалі війни, про боротьбу, сутички й суперечки між богами й богинями, доволі показовим $є$ сюжет про «яблуко розбрату» тощо. Цікаво, що Афріна, яка була однією 3 дванадцяти великих олімпійських богів, вважалась богинею мудрості, військової стратегії і тактики, а також богинею справедливої війни.

Давньогрецький мислитель Платон (у рамках розробленої ним теорії досконалого державного устрою) розглядав такі ситуації, які виключали б саму можливість будь-якої конфронтації. У зв'язку з цим він аналізуе чотири головні чесноти найбільш досконалої держави мудрість, мужність, розсудливість і справедливість. Наприклад, встановлення й дотримання справедливості дозволяе зберегти рівновагу сил у державі. В «ідеальній державі» Платона $є$ воїни, які готові виступити в похід у будь-який час [17, с. $130,205,234]$. Розуміння природи «агонального» у вченні про «ейдоси» у фрілософії Платона виражається через протиставлення світу ідей - світові речей, а у вченні про державу - через різні форми державного устрою. Мислитель наголошував, що кожна людина здатна до взаєморозуміння й співпраці з іншими, проте схильність до ненависті, ворожнечі та насильства заважає позитивній взаємодії між людьми. Платон розглядав війну як найбільше зло.

Давньогрецький фрілософр Аристотель у своїх працях намагався з'ясувати причини ситуацій протиборства у суспільстві, найперше, між очільниками держави та населенням. На його думку, ці причини можуть бути надзвичайно різноманітними: відсутність рівності за гідністю [1, с. 528]; економічні здобутки та почесті (прагнення отримати прибуток і шану веде до взаємного роздратування людей, не тому, що вони бажають отримати їх для самих себе, а тому, що вони бачать, як одні - справедливо, а інші - несправедливо користуються цими благами [1, с. 530]); нахабність і користолюбність («якщо ті, які знаходяться при владі, проявляють нахабство і користолюбство, то населення починає вороже ставитися і до них, i до того державного ладу, який дає їм таку можливість» [1, с. 530]); страх (люди, які спричинили образу, бояться нонести кару; ті, кому загрожує небезпека стати жертвою образи, бажають упередити можливість образи ще до їі нанесення [1, с. 531]); презирство з боку керівництва держави (велика кількість громадян не бере участі в управлінні державою, хоча усвідомлюе свою силу [1, с. 531]); різноманітність племен у складі населення; неприйнятність території для створення єдиної держави [1, с. 533] та ін.

У контексті досліджуваної теми значення римського права є таким же важливим, як і теоретичне осмислення конфліктів, розпочате давньогрецькими філософрами. Адже в рамках римського права не тільки вирішувались питання приватних суперечок, що виникали в сощіумі й вимагали свого вирішення, римське право було якісним кроком уперед у вирішенні будь-яких колізій, що виникали між людьми.
Отже, вже в античну добу видатні мислителі (Геракліт, Геродот, Емпедокл, Епікур, Платон, Аристотель, Цицерон та ін.) вивчали різні аспекти конфронтаційної взаємодії між людьми, соціальними групами, суспільствами і країнами, а також проблеми згоди і протиборства, війни і миру. Давньогрецькі мислителі більше цінували не війну й протиборство, а мир і згоду. Розроблене римськими юристами право стало потужним механізмом для врегулювання різного роду конфрліктів. Оскільки у спадщині античних мислителів містились детальні описи багатьох воєн та конфліктів, то в епоху Середньовіччя та добу Відродження вчені почали більш глибоко осмислювати сутність цих явищ.

В античній фрілософої джерело конфрліктів мислителі вбачали у природі, у бутті, а в середньовічній фрілософії це було пов'язано з відсутністю або нестачею добра, Бога в душі людини. В епоху Середньовіччя уявлення про конфрлікти та їхні витоки зводились до Божественного начала і свідчили про людську гріховність та відчуження від Бога.

У середньовічній фрілософіï природа конфолікту виражалась через такі протиставлення: розум віра, істина - одкровення. Особливий інтерес викликало протистояння християнської догми і dpiлософської думки, протиставлення Бога i prima materia, духу і тілесної плоті. Конфронтаційне начало простежувалось у питаннях віри і знання, у протидії язичнищького і християнського, в боротьбі світла й темряви, добра і зла, у стосунках між Богом і тварним світом, у протистоянні «Граду Божого» і «Граду земного». Особливе значення мало зіткнення й протиборство християнської культури з нехристиянською, конфрлікт світського i священного, криза церкви і посилення еретичного руху, відокремлення теології та фрілософріï, конфлікт віри і розуму в номіналізмі та реалізмі середньовічної схоластики [23].

Уявлення про подвійну природу людини, що виникае у Середньовіччі, екстраполюеться на весь світ: конфолікт душі й тіла (принципово відмінних складових людини) трансформуеться в уявлення про протилежності, які в процесі свого розвитку, проходячи стадію протиріччя, породжують нову якість [23].

Однією з найвідоміших у добу Середньовіччя була теорія «виправдання Бога» християнського богослова і фрілософра Аврелія Августина, який стверджував, що всі прояви зла (війни, конфрлікти, хвороби тощо) походять не від Бога. На думку Аврелія Августина, зло не має своєї власної субстанційної природи, а характеризується лише недостачею або відсутністю добра, що походить від людини, будучи проявом їі вільної волі [14]. Розвиваючи цю думку, італійський dpiлософр і теолог Фома Аквінський припустив, що в житті суспільства допустимі війни, якщо вони санкціоновані державою [4].

Відомо, що християнська фрілософрія (особливо на початковій стадії свого розвитку) прагнула довести переваги миру, злагоди і братерства між людьми. Але якщо на рубежі I-III ст. н.е. представники християнства розвивали аргументацію, спрямовану проти збройних зіткнень, агресивних устремлінь, то вже у IV ст. н.е. принцип несумісності воєн 3 вченням Христа ставиться під сумнів. Все I тисячоліття від Різдва Христово- 
го - це період перетворення християнства з віри небагатьох людей, гнаних світською владою, на віру більшості, яка підтримуеться світською владою. Цей процес характеризуеться поступовим переродженням миротворчих прагнень, властивих раннім християнам, на загарбницьку ідеологію, що породила Хрестові походи, в ході яких «вогнем і мечем» здійснювалась християнізація нових народів [24; 27].

В епоху Відродження були сформовані дві протилежні думки, які пояснювали причини конфрліктів у соціумі, адже одні автори бачили причину конфрліктності у недосконалій системі соціальної взаємодії, а інші - у недосконалості людської особистості та іï негативних рисах. Основним конфрліктом фрілософії періодів Середньовіччя й Відродження було протистояння релігійних і світських уявлень про конфрліктні ситуащії та мир у цілому. Основною причиною конфліктності у названі періоди вважалася схильність людини до егоїзму й самолюбства та недосконалість соціального ладу держави [22, с. 138-140].

Італійський мислитель, політичний діяч i dpiлософр Н. Макіавеллі одним 3 перших спробував систематизувати уявлення про різнопланові конфрлікти. Для його теоретичних постулатів була характерною відмова від релігійних поглядів на джерела й рушійні сили суспільного розвитку, оскільки він наполягав на тому, що конфрлікт є універсальним і безперервним станом соціуму через недосконалу природу людини та прагнення різних груп населення до постійного й необмеженого збагачення. Автор виділяв позитивні сторони конфлікту і стверджував, що для зменшення негативного впливу конфліктів на суспільство необхідно правильно на нього впливати, і тільки держава здатна із цим завданням впоратися [5]. Сучасні дослідники вважають, що у теорії Н. Макіавеллі присутній біологічний редукціонізм [5, с. 245].

В епоху Відродження мислителі звертаються до класичної спадщини Давньої Греції та Риму, вони засуджують будь-які конфрлікти й соціальні зіткнення. У цей час філософри практично не використовують релігійні погляди для інтерпретації конорліктів, виникає кондрлікт гуманізму й ренесансної фрілософрської думки із середньовічною теологією та схоластикою, активізуеться протистояння натурфілософрії та окультної фрілософріï, розгортається непримиренна боротьба римськокатолицької церкви з редрорматорськими вченнями. Конфлікт відіграє важливу роль у становленні новоевропейської науки. Актуалізуеться неприйняття авторитетів і традищій попередніх століть, антитеза: теїзм - пантеїзм [23; 24].

Мислитель епохи пізнього Відродження Еразм Роттердамський; англійський юрист, фрілософр, письменник-гуманіст Томас Мор; англійський фрілософр, історик і політик Френсіс Бекон та інші фрілософи-гуманісти виступили 3 різким засудженням середньовічних смут, соціальних заворушень і кровопролитних міжусобиць. Свропейські просвітителі виступали за мир і злагоду між людьми, визнаючи їх вирішальним чинником суспільного розвитку $[16 ; 28]$.

Е. Роттердамський відзначав, що «війна солодка для тих, хто їі не знає», вказуючи на наявність власної логіки у кожного розпочатого конфрлікту, який розростається, подібно до ланцюгової реакції, втягуючи в орбіту свого впливу все нові й нові верстви населення країни. Е. Роттердамський відзначав наявність елемента непередбачуваності у розростанні конфліктів [20, с. 212]. У своєму творі “Скарги світу» видатний гуманіст зазначав, що у процесі війни «все прекрасне і корисне знищуеться» [19, с. 40], він закликав усі народи та їхніх правителів до миру й мирного співіснування, звертаючись як до очільників держав, так і до простих людей із проханням боротися за мир [19, с. 58].

Ф. Бекон проаналізував причини конорліктів усередині країни, матеріальні, політичні та психологічні умови сощіальних заворушень, можливі способи їх подолання. Однією з причин виникнення сощіальних заворушень він вважав тяжке матеріальне становище народу. Ф. Бекон підкреслював: «заколоти, викликані черевом, $є$ найгіршими» [6, с. 242]. Філософр наголошував, що государі пов'язані зі своїми державами і не повинні нехтувати думкою верств суспільства і сенату, вирішуючи всі питання свавільно і на власний розсуд. Крім політичних помилок в управлінні $\Phi$. Бекон вказував кілька психологічних причин соціальних заворушень: «гостре і кілке слово в устах государя», «заздрість у суспільному житті», «пасквілі й крамольні промови, коли вони часті й сміливі, а також неправдиві чутки, що порочать уряд, коли вони виникають часто і охоче підхоплюються» [6, с. 242, 371, 381, 382, 385, 386].

Англійський фрілософр-матеріаліст Т. Гоббс та англійський фрілософр і педагог Д. Лок, як палкі прихильники буржуазних свобод і рівності стартових можливостей [18], говорили про людину, як про самощінну незалежну істоту [33]. У opiлософрiї Т. Гоббса аналізувалась війна як форма прояву природи людини, а у вченні Дж. Лока досліджувалась проблема сощіального конфрлікту й толерантності. Зокрема, Т. Гоббс вважав, що людина - істота егоїстична й самолюбива, заздрісна й лінива, що природним станом суспільства $€$ боротьба всіх проти всіх, в котрій люди виступають або у якості ворогів, або в якості партнерів. 3 огляду на такі песимістичні оцінки, він вважав, що конфлікти зумовлені соціальною нерівністю та порочністю людей, що вирішувати конфрлікти можна шляхом погроз, примусу, залякування та застосування державного насильства [10, с. 158 , 167-168]. На думку мислителя, війна хоча й відповідає природі людини, але вона є надзвичайно згубною для людей. Концепція «війни всіх проти всіх» як природного стану, була обгрунтована Т. Гоббсом у «Левіафрані» (1651) [7; 32]. Мислитель використовуе образ Левіафрана для опису всемогутньої держави. Осмислюючи проблему війни та їі соціальних наслідків, Т. Гоббс був переконаний, що країна-загарбниця, їі армії та полководщі, які грабують інші народи, є «жахливим чудищем» [9, с. 271]. Серйозною хворобою держави англійський філософр вважав «невтомну жадобу до розширення своїх володінь» [8, с. 259]. Філософр виділяе три форми державної влади: демократію, аристократію і монархію, віддаючи перевагу монархії. Теорія суспільного договору Т. Гоббса була покликана пояснити необхідність створення держави, якій громадяни передають частину своїх прав і яка підтримуе порядок у сус- 
пільстві, іноді спираючись на легітимний примус i насильство. Саме держава покликана покласти край стану "війни всіх проти всіх». Ця теорія Т. Гоббса послужила прообразом для створення інших концепцій договірного походження держави [22, с. 138-145]. Одночасно з теорією суспільного договору починає зароджуватися і концепція правової держави з їі принципом поділу влади та верховенством права.

Якщо у XVII ст. були створені якісно нові теорії та концепщії, присвячені різноплановим конорліктам, то у XVIII ст. англійські демократи й фрранцузькі просвітителі Д. Прістлі, Ш. Монтеск'є, Д. Дідро, Вольтер виступили з принциповою критикою збройних конфрліктів, засуджуючи завоювання й насильство. Вони розглядали збройні конфрлікти як пережиток «варварської епохи», вважаючи, що тільки ліквідащія існуючих фpeодальних відносин призведе до «вічного миру» [15]. У працях мислителів цього періоду увага була зосереджена на пошукові ращіональних фрорм організації суспільного життя, які змогли б усунути причини соціальних конфрліктів, що вкорінені у віджилих формах державного устрою.

Французький фрілософр Жан-Жак Руссо стверджував, що людина за своєю природою є миролюбною і доброю, а передумови для конфлікту зароджуються в умовах недосконалої соціальної системи. Мислитель ділив історію людства на три періоди: спочатку існуе «природний стан», коли люди є вільними й рівними, потім розвиток цивілізації приводить до втрати людьми свободи й рівності i, нарешті, уклавши «суспільний договір», люди знову знайдуть втрачену гармонію суспільних відносин, "вічний мир» і єдність. У своєму творі «Судження про вічний мир» (1782) Руссо чітко висловив свою позицію, виступаючи проти загарбницьких війн [3]. Жан-Жак Руссо вважав, що люди є миролюбними за своєю природою, а конфлікти виникають у суспільстві через недоліки та прихильність людей до приватної власності. Саме демократична держава та спеціально організоване виховання можуть стати засобом відновлення відносин миру й згоди [21].

Шотландський економіст і фрілософр-етик Адам Сміт у своїй книзі «Теорія моральних почуттів» виступив послідовним прихильником «любові до себе» при неодмінній гармонії своєкорисливих інтересів із загальними устремліннями людей до благополуччя і щастя [26]. Така позиція А. Сміта була зрозумілою у період становлення й утвердження капіталізму епохи вільної конкуренції, адже вона служила засобом попередження, за- лагодження й розв'язання конфрліктів у ту епоху, коли набирав силу індивідуалізм й зберігалися колективістські традиції колишнього суспільного устрою. На його думку, в основі будь-якого конфрлікту лежить поділ суспільства на класи, а також економічне суперництво. А. Сміт вважав, що основна причина, яка рухає людиною у пї прагненні поліпшити своє становище, підвищити соціальний статус, полягає в тому, щоб «відзначитися, звернути на себе увагу, викликати схвалення, похвалу, співчуття або отримати супроводжуючі їх вигоди» [26, с. 121]. Згодом у своєму відомому дослідженні про природу й причини багатства народів він поставив на перше місце економічні інтереси разом з турботою людини про власне матеріальне благополуччя, яке не було б перешкодою на шляху до загального блага [25].

Висновки i пропозиції. Отже, наукове осмислення конфрліктів починається в ранній період становлення фрілософрької думки, а розробка фундаментальних конфліктологічних концепцій - у 1950-1970 роках.

Конфрлікт розглядається нами як одна з форм життедіяльності будь-якого соціуму. Конфлікт $\epsilon$ певним вектором, "началом», що пронизує всі сорери життя сусупільства, редукуючись в особливі способи взаємодії, які є характерними для конкретної сфери суспільного життя. Будь-який конфрлікт може приводити i до деструктивних, і до конструктивних наслідків. Пошук оптимальних засобів і способів декондліктизащії різноманітних відносин у державі й суспільстві варто розпочати 3 глибокого аналізу конкретного конфлікту, визначення його суті та виявлення основних умов врегулювання. Отже, інтегративний підхід дозволяє: а) проаналізувати й систематизувати причини й чинники конфліктизації певного соціуму, які дають найбільш повну картину появи та ескалації будь-якого конфлікту; б) подолати обмеженість існуючих методологічних концепщій і поєднати найбільш дієві засоби деконфрліктизації та стабілізації соціуму; в) реактуалізувати ті конфліктологічні ідеї, які не втратили своєї значущості до цього часу і $є$ важливими для припинення російсько-українського збройного кондлікту на теренах України, деконфрліктизації українського суспільства та реінтеграції населення окупованих територій.

У наступних статтях ми плануемо розглянути процес розвитку конфрліктологічних ідей, які репрезентовані в історії фрілософрської думки (від німецької класичної фрілософрії до фрілософрї̈ XXI ст.) крізь призму інтегративного підходу.

\section{Список літератури:}

1. Аристотель. Сочинения: В 4-x m. Т. 4. Москва : Мысль, 1983. 830 с.

2. Асмус В.Ф. История античной фбилософби. Москва : Высш. шк., 1965. 320 с.

3. Асмус В.Ф. Жан Жак Руссо. Москва : Знание, 1962. 48 с.

4. Бандуровский К.В. Проблемы этики в «Сумме теологии» Фомы Аквинского. Вопросы фбилософбии. 1997. № 9. C. $156-162$.

5. Баткин Л.М. Итальянское Возрождение: проблельь и люди. Москва : Наука, 1989. 272 с.

6. Бэкон Ф. Сочинения. В 2 m. Т. 2. 2-е изд. Москва, 1979. 570 с.

7. Гоббс Т. Левіаббан / Пер. з англ. Київ : Дух і Літера, 2000. 606 с.

8. Гоббс Т. Сочинения: в 2 m. / Пер. с лат. и англ.; сост.; ред. изд. авт. вступ. ст. и примеч. В.В. Соколов. Москва : Мысль, 1989. Т. 1. 622 с.

9. Гоббс Т. Сочинения: в 2 m. / Сост., ред., авт. примеч. В. В. Соколов; пер. с лат. и англ. Москва : Мысль, 1991. T. $2.731 \mathrm{c}$.

10. Гоббс Т. Филособские основания учения о гражданине. Москва-Минск : АСТ, Харвест, 2001. 304 с.

11. Ивин А.А. Введение в фбилософию истории. Москва : Владос, 1997. 288 с. 
12. История философии: учебник для высших учебных заведений / Под ред. В.П. Кохановского, В.П. Яковлева. 5-е изд. Ростов н/Д : Феникс, 2007. 575 с.

13. Конфуций. Суждения и беседы. СПб : Кристалл, 2001. 1120 с.

14. Майоров Г.Г. Форлирование средневековой фблософби. Латинская патристика. Москва : Мысль, 1979. C. $181-340$.

15. Монтескье Ш.Л. О духе законов / Сост., пер. и коммент. А. В. Матешук. Москва : Мысль, 1999. 672 с.

16. Осиновский И.Н. Эразл Роттердамский и Толас Мор: из истории ренессансного христианского гуманизма. Москва : МГПУ, 2006. 217 с.

17. Платон. Государство. Собрание сочинений в 4-х толах. Т. 3. Москва : Мысль, 1994. 654 с.

18. «Послание о веротерпимости» Джона Локка: точки зрения. Екатеринбург : Изд-во Урал. ун-та, 2002.275 с.

19. Роттердамский Э. Жалобы мира. Трактаты о вечнол мире. Москва : Соцэкгиз, 1963. С. 39-81.

20. Роттердамский Эразм. Философбские произведения / Пер. и коммент. Ю.М. Каган. Москва : Наука, 1986.704 с.

21. Руссо Ж.-Ж. Об общественнол договоре: трактаты. Москва : ТЕРРА - Книжный клуб: КАНОН-пресс-Ц, 2000. $544 \mathrm{c}$

22. Семенов Владимир. Мыслители эпохи Возрождения о природе и роли конфликта. История зарубежной конфбиктологии. 2-е. Москва : Юрайт, 2018. Т. І. С. 120-145.

23. Смагин Ю.Е. Историко-фбилософбский контекст конфбликта. URL: https://cyberleninka.ru/article/n/ novoevropeyskaya-nauka-stolknovenie-i-kompromiss

24. Смагин Ю.Е. Кондликт науки и религии в Новое время. Вестник Русского Христианского Гуманитарного Института. 2004. № 5. С. 200-206. URL: https://rhga.ru/upload/iblock/24e/24efbccdafe8a1610836eab532c4417c.pdf

25. Смит А. Исследование о природе и причинах богатства народов. Москва : Эксмо, 2007. 960 с.

26. Смит А. Теория нравственных чувств. Москва : Республика, 1997. 352 с.

27. Современная христианская фрилософия. Москва : ЦИНО общества «Знание» России, 1997. 288 с.

28. Субботин А.Л. Фрэнсис Бэкон. Москва : Мысль, 1974. 175 с.

29. Статті і матеріали, присвячені Гераклітові. Львів : Вид-во Львівського держ. ун-ту імені Івана Франка, $1963.58 \mathrm{c}$

30. Фрагменты ранних греческих философов. Москва : Наука, 1989. Ч. 1. 576 с.

31. Цицерон. Диалоги: О государстве. О законах / Отв. ред. С.Л. Утченко. Москва : Наука, 1966. 224 с.

32. Шмитт К. Левиабан в учении о государстве Толаса Гоббса / Пер. с немецкого Д.В. Куницына. СПб : «Владимир Даль», 2006. 300 с.

33. Яковлев А.А. Завешание Джона Локка, привержениа мира, фбилософба и англичанина. Москва : Изд-во ин-та Гайдара, 2013. 432 с.

34. Ян Хин-Шун. Древнекитайская фбилософия. Москва : Мысль, т. 1-2, 1972-1973. Т. 1. 363 с.

35. Averianova N.M., Voropayeva T.S. International armed conflict in Ukraine: the ethno-philosophical dimension. Modern scientific researches. Minsk, Belarus, 2019. Issue 9. Part 2. P. 107-114.

36. Averianova N.M., Voropayeva T.S. Features of settlement of modern armed conflicts: integrative approach. Organization of scientific research in modern conditions '2020: conference proceedings. Seattle : KindleDP, 2020. 649 p. P. 477-481.

37. Averianova Nina, Voropaieva Tetiana. Transformation of the Collective Identity of Ukrainian Citizens After the Revolution of Dignity (2014-2019). Kyiv-Mohyla Humanities Journal. 2020. No 7. P. 45-71.

\section{References:}

1. Aristotle. (1983) Sochineniya: V 4-kh t. T. 4 [Works: In 4 volumes. Vol. 4]. Moscow: Mysl, 830 p. (in Russian)

2. Asmus, V.F. (1965) Istoriya antichnoj filosofii [History of Ancient Philosophy]. Moscow: Vyssh. shk., 320 p. (in Russian)

3. Asmus, V.F. (1962) Zhan Zhak Russo [Jean-Jacques Rousseau]. Moscow: Znanie, 48 p. (in Russian)

4. Bandurovsky, K.V. (1997). Problemy etiki v «Summe teologii» Fomy Akvinskogo [Problems of Ethics in the «Sum of Theology" by Thomas Aquinas]. Voprosy filosofii, no. 9, pp. 156-162. (in Russian)

5. Batkin, L.M. (1989) Italyanskoe Vozrozhdenie: problemy $i$ lyudi [Italian Renaissance: Problems and People]. Moscow: Nauka, 272 p. (in Russian)

6. Bacon, F. (1979) Sochineniya. V 2 t. T. 2. 2-e izd. [Works. In 2 vols. T. 2. 2nd ed.]. Moscow, 570 p. (in Russian)

7. Hobbes, T. (2000). Leviafan [Leviathan]. Kyiv: Dux i Litera, 606 p. (in Ukrainian)

8. Hobbes, T. (1989). Sochineniya: $v 2 t$ [Works: in 2 volumes]. Moscow: Mysl, T. 1, 622 p. (in Russian)

9. Hobbes, T. (1991). Sochineniya: $v 2 t$ [Works: in 2 volumes]. Moscow: Mysl, T. 2, 731 p. (in Russian)

10. Hobbes, T. (2001). Filosofskie osnovaniya ucheniya o grazhdanine [Philosophical foundations of the doctrine of the citizen]. Moscow-Minsk: AST, Harvest, 304 p. (in Russian)

11. Ivin, A.A. (1997). Vvedenie v filosofiyu istorii [Introduction to the philosophy of history]. Moscow: Vlados, $288 \mathrm{p.}$ (in Russian)

12. Istoriya filosofii: uchebnik dlya vysshikh uchebnykh zavedenij (2007) [History of Philosophy: Textbook for Higher Educational Institutions] / Pod red. V.P. Kokhanovsky, V.P. Yakovleva. 5-e izd. Rostov-on-Don: Feniks, 575 p. (in Russian)

13. Confucius (2001) Suzhdeniya i besedy [Judgments and conversations]. SPb: Kristall, 1120 p. (in Russian)

14. Mayorov, G.G. (1979) Formirovanie srednevekovoj filosofii. Latinskaya patristika [Formation of medieval philosophy. Latin patristics]. Moscow: Mysl, pp. 181-340. (in Russian)

15. Montesquieu, S.L. (1999) O dukhe zakonov [On the spirit of laws]. Moscow: Mysl, 672 p. (in Russian)

16. Osinovsky, I.N. (2006) Erazm Rotterdamskij $i$ Tomas Mor: iz istorii renessansnogo khristianskogo gumanizma [Erasmus of Rotterdam and Thomas More: From the History of Renaissance Christian Humanism]. Moscow: MGPU, 217 p. (in Russian)

17. Platon (1994) Gosudarstvo. Sobranie sochinenij v 4-kh tomakh. T. 3 [State. Collected works in 4 volumes. T. 3]. Moscow: Mysl, 654 p. (in Russian)

18. «Poslanie o veroterpimosti» Dzhona Lokka: tochki zreniya (2002) [John Locke's Message of Tolerance: Perspectives]. Yekaterinburg: Izd-vo Ural. un-ta, 275 p. (in Russian)

19. Rotterdam, E. (1963) Zhaloby mira. Traktaty o vechnom mire [Complaints of the world. Treatises on eternal peace]. Moscow: Soczekgiz, pp. 39-81. (in Russian) 
20. Rotterdam, Erasmus (1986) Filosofskie proizvedeniya [Philosophical works]. Moscow: Nauka, 704 p. (in Russian)

21. Rousseau, J.-J. (2000). Ob obshhestvennom dogovore: traktaty [On the social contract: treatises]. Moscow: TERRABook Club: CANON-press-C, 544 p. (in Russian)

22. Semyonov, Vladimir (2018) Mysliteli epokhi Vozrozhdeniya o prirode i roli konflikta. Istoriya zarubezhnoj konfliktologii. 2-e [Renaissance thinkers on the nature and role of conflict. History of foreign conflict management. $\left.2^{\text {nd }}\right]$. Moscow: Yurayt, vol. I, pp. 120-145. (in Russian)

23. Smagin, Yu.E. Istoriko-filosofskij kontekst konflikta [Historical and philosophical context of the conflict]. URL: https://cyberleninka.ru/article/n/novoevropeyskaya-nauka-stolknovenie-i-kompromiss (in Russian)

24. Smagin, Yu.E. (2004) Konflikt nauki i religii v Novoe vremya [Conflict between science and religion in modern times]. Vestnik Russkogo Khristianskogo Gumanitarnogo Instituta, no. 5, pp. 200-206. URL: https://rhga.ru/ upload/iblock/24e/24efbccdafe8a1610836eab532c4417c.pdf (in Russian)

25. Smith, A. (2007) Issledovanie o prirode i prichinakh bogatstva narodov [Research on the nature and causes of the wealth of nations]. Moscow: Eksmo, 960 p. (in Russian)

26. Smith, A. (1997) Teoriya nravstvennykh chuvstv [Theory of moral feelings]. Moscow: Respublika, 352 p. (in Russian)

27. Sovremennaya khristianskaya filosofiya (1997) [Contemporary Christian philosophy]. Moscow: CzINO obshhestva «Znanie» Rossii, 288 p. (in Russian)

28. Subbotin, A.L. (1974) Frensis Bekon [Francis Bacon]. Moscow: Mysl, 175 p. (in Russian)

29. Statti i materialy, prysvyacheni Geraklitovi (1963) [Articles and materials devoted to Heraclitus]. Lviv: Vyd-vo Lvivskogo derzh. un-tu imeni Ivana Franka, 58 p. (in Ukrainian)

30. Fragmenty rannikh grecheskikh filosofov (1989) [Fragments of the early Greek philosophers]. Moscow: Nauka, ch. 1, 576 p. (in Russian)

31. Ciceron (1966) Dialogi: O gosudarstve. O zakonakh [Dialogues: About the state. About laws]. Moscow: Nauka, 224 p. (in Russian)

32. Schmitt, K. (2006) Leviafan v uchenii o gosudarstve Tomasa Gobbsa [Leviathan in the doctrine of the state by Thomas Hobbes]. SPb: «Vladimir Dal», 300 p. (in Russian)

33. Yakovlev, A.A. (2013) Zaveshhanie Dzhona Lokka, priverzhencza mira, filosofa i anglichanina [Testament of John Locke, an adherent of peace, a philosopher and an Englishman]. Moscow: Izd-vo in-ta Gajdara, 432 p. (in Russian)

34. Yan Hin-Shun (1972-1973) Drevnekitajskaya filosofiya [Ancient Chinese philosophy]. Moscow: Mysl, t. 1-2. T. 1. 363 p. (in Russian)

35. Averianova, N.M. \& Voropayeva, T.S. (2019) International armed conflict in Ukraine: the ethno-philosophical dimension. Modern scientific researches. Minsk, Belarus, issue 9, part 2, pp. 107-114.

36. Averianova, N.M. \& Voropayeva, T.S. (2020) Features of settlement of modern armed conflicts: integrative approach. Organization of scientific research in modern conditions '2020: conference proceedings. Seattle: KindleDP, pp. 477-481.

37. Averianova, Nina \& Voropaieva, Tetiana (2020) Transformation of the Collective Identity of Ukrainian Citizens After the Revolution of Dignity (2014-2019). Kyiv-Mohyla Humanities Journal, no. 7, pp. 45-71. 